\title{
STIGMA AND ATTITUDES TOWARDS MENTAL HEALTH DISORDERS: A CROSS SECTIONAL STUDY AT A PRIVATE UNIVERSITY IN MALAYSIA
}

\author{
Sangeeta Roop Kaur Despande1, *Irma Wati binti Ngadimon ${ }^{1}$ and Nor Liana Che Yaacob² \\ ${ }^{1}$ Faculty of Pharmacy, MAHSA University, 42610 Jenjarom, Selangor, Malaysia \\ ${ }^{2}$ School of Pharmacy, Management and Science University (MSU), 40100 Shah Alam, Selangor, Malaysia
}

Corresponding author: Irma Wati binti Ngadimon

Email: irma@mahsa.edu.my

\begin{abstract}
The number of mental health problems among the young people in Malaysia is increasing, and this is worrying. Prompt action is needed as the young generation especially university students are the future leaders of the country. This study aimed to evaluate the level of stigma and attitudes of university students towards mental health disorders since limited study regarding this issue conducted in Malaysia. This is a cross-sectional study design whereby 496 students from MAHSA University were asked to complete a pre-validated questionnaire. The questionnaire consisted of three main sections which were demographic, measures of knowledge and attitudes of respondents towards mental health disorders. The findings showed that there was a significant difference between knowledge score of the different age groups, ethnicity, faculty and current education level of respondents. Besides that, significant differences were reported between attitude score of the different age groups, faculty and current education level of the respondents. It was also found that there was a statistically significant positive correlation between mental health knowledge and attitudes towards mental health disorders. Overall, the respondents displayed good knowledge and attitude towards mental health disorders.
\end{abstract}

Keywords: Mental health, knowledge, attitudes, student, university students

\section{INTRODUCTION}

It is believed that one in four people will suffer mental disorders. WHO states that about 450 million people across the globe are currently experiencing mental disorders making it one of the chief causes of ill-health worldwide ${ }^{1}$. Mental health disorder refers to a wide range of mental health conditions that affect the mood, thinking and behaviour. It includes depressive disorders, anxiety, schizophrenia, drug and alcohol dependency ${ }^{2}$. In Malaysia, the mental health problems among the population has become tripled over the past 20 years with estimated lost about US\$10.6 billion (RM43.6 trillion) for 2010 and projected to rise to US\$24.3 billion (RM99.9 billion) by

$2030^{3}$.

Thornicroft $\mathrm{G}$ et al. defined stigma as an overarching term that contains three elements: problems of knowledge (ignorance), problems of attitudes (prejudice), and problems of behaviour (discrimination) ${ }^{4}$. Despite various efforts by the government and non-governmental organisations in Malaysia to raise awareness regarding mental health, the knowledge and attitude of the Malaysian public is still found to be lacking as shown in a study conducted by Yeap and Low ${ }^{5}$. There is also a more recent study which was conducted among the British, Hong Kong and Malaysian public indicated Malaysians as having the poorest attitude towards mental health ${ }^{6}$. Another study in Universiti Sains Malaysia revealed a moderate level of knowledge regarding mental health with Chinese, particularly the females, have a higher knowledge on mental health compared to the Malays and Indians ${ }^{7}$. In a study conducted to assess the stigmatising attitudes towards mental illness, it was found that there is profound discriminating attitudes towards the mentally ill ${ }^{8}$.

The public tends to view mental illness as something negative and disgraceful. People are predisposed to associate mental disorders with psychosis. This is due to the fact, that in the past, mental illness was described in a negative light that caused people to develop a fear towards individuals with mental disorders and had a tendency of rejecting and devaluing them? .

Malaysia, which falls into the category of rapidgrowing nations, finds its people trying to cope with the rapid change of pace, thus leading to an increase in their stress levels and tension faced at work, school and society. This stress leads to a disruption in their physical and mental health ${ }^{5}$. A recent study in Malaysia indicated that adults above 16 years of age suffering from mental health problems have increased over the years from $11.2 \%$ in 2006 to $29.2 \%$ in 2014, indicating an $18 \%$ increase in less than 10 years ${ }^{10}$. 
Studies also showed that the number of mental health illness cases among university students raised tremendously each year ${ }^{11}$. Students studying in higher learning institutions are at more risk to develop mental health problems compared with their peers of similar age groups ${ }^{12}$. Obviously, as university students are the country's leaders of the future, these issues need to be tackled with utmost urgency. In Malaysia, the available study on mental health focused only on medical students rather than on the general student's population, in which revealed that a certain proportion of medical students experienced mental health problems ${ }^{13,14}$. Hence, specific intervention should be carried out by university authorities as mental health problems not only will lead to poor academic performance but can further lead to suicidal attempt ${ }^{15}$.

This study aimed to evaluate the stigma and attitude of MAHSA University students towards mental health disorder. To our best knowledge, this is the first study in Malaysia that include students with varied field of studies. The findings of this study are purported to not only benefit the targeted group, but the community as a whole by increasing mental health literacy in the public and reducing the stigma surrounding mental health problems.

\section{MATERIALS AND METHOD}

\section{Study design and sampling}

This study performed a cross-sectional survey with a stratified random sample of MAHSA University students. A sample size of 356 was required from a population of 4696 students in MAHSA University, based on the RAOSOFT calculator, however, 500 students were recruited to increase the power of the study and allow for subgroup analysis. With the confidence interval level of .95, at 95\% power and the alpha of 0.05 , the estimated sample size of 356 was computed. Thus, the total number of 500 respondents recruited for this study was sufficient to represent the students' population studying in MAHSA University. Students from MAHSA University who were, at the time, currently in the process of furthering their studies and were active students of MAHSA University were included. Cluster sampling was then utilized to recruit the respondents based on their field of studies. All respondents read, understood and signed a written consent form prior to participating in the study. Ethical approval was obtained from Research and Ethics Committee of MAHSA University (Ref. RMC/EC12/2018).

Data was collected using self-administered questionnaires that comprised three parts of close ended questions which are demographic characteristics of participants, measures of knowledge and measures of attitudes. The stigma- related mental illness knowledge of the participants was measured using the 12-item Mental Health Knowledge Schedule (MAKS) ${ }^{16,17}$. The first six items of covered components of mental health knowledge related to employment, recognition, support, treatment, recovery and help-seeking. Items 7 to 12 assess opinions about the conditions that are considered to be a type of mental illness which are "Depression", "Stress", "Schizophrenia", "Bipolar disorder (manic depression)", "Drug addiction" and "Grief"16,18. The stigma section required the respondent to rate the level of agreement and disagreement of each item using a five-point Likert scale. Items 1, 2, 3, 4, 5, 7, 9, 10 and 11 were valued at 5 points for "strongly agree", 4 points for "agree", 3 points for "neither agree nor disagree" for the purposes of determining a total score, 2 points for "disagree" and 1 point for "strongly disagree". Items 6, 8 and 12 were coded reversely to indicate the direction of the correct response whereby they were valued at 5 points for "strongly disagree" up to 1 point for "strongly agree". The total score for the knowledge section was 60 with a higher score indicated better knowledge.

The attitudes section consisted of a 9-item attitude scale $^{5}$. The items were rated on a four-point Likert scale from "strongly agree" to "strongly disagree" whereby the minimum possible score was 9 and the highest possible score is 36 . Higher scores on the attitude scale indicated better attitudes towards mental health disorders. The content validity was verified by an expert to ensure the questionnaires elements are relevant and pilot test was performed among 40 respondents. The Cronbach's alphas for knowledge and attitude segments were 0.63 and 0.7 respectively.

\section{Data Analysis}

Both descriptive and analytical statistics including Spearman correlation analysis, Kruskal-Wallis test and Man-Whitney test were performed using Statistical Package for Social Sciences (SPSS) software version 23.0. A p-value $<0.05$ was considered statistically significant.

\section{RESULTS}

\section{Demographic characteristics}

A total of 496 students completed the questionnaires, giving an overall response rate of $99.2 \%$. The majority of the respondents were female $(69.8 \%)$, aged range was 18 to $21(59.5 \%)$, with a mean age of 20.8 years-old (SD 2.2). Almost half of the respondents were Chinese $(45.4 \%)$ followed by Malays (29.4\%), Indian (17.9\%) and the remaining were of other ethnicities (7.3\%). The overall sociodemographic status of the participants is presented in Table 1. 
Table 1: Demographic data of the respondents $(n=496)$

\begin{tabular}{lcc}
\hline Characteristics & $\mathbf{n}$ & Percentage (\%) \\
\hline Age & & \\
$18-21$ & 295 & 59.5 \\
$\geq 22$ & 201 & 40.5 \\
Gender & 150 & 30.2 \\
$\quad$ Male & 346 & 69.8 \\
Female & & \\
Ethnicity & 146 & 29.4 \\
$\quad$ Malay & 225 & 45.4 \\
Chinese & 89 & 17.9 \\
Indian & 36 & 7.3 \\
Others & & 12.9 \\
Faculty & 64 & 7.9 \\
$\quad$ Health \& Sports Science & 39 & 11.5 \\
Engineering & 57 & 12.1 \\
Medicine & 60 & 12.3 \\
Dentistry & 61 & 16.7 \\
$\quad$ Nursing & 83 & 12.5 \\
Pharmacy & 62 & 14.1 \\
Business, Finance \& Hospitality & 70 & \\
Foundation in Science & & 48.6 \\
Current education level & 241 & 51.4 \\
Foundation/Diploma & 255 & \\
Degree & & 22.6 \\
Experience of mental health disorders in self or others & & 77.4 \\
Yes & 112 &
\end{tabular}

\section{Knowledge}

The mean score for knowledge section obtained were 41.85 (SD 3.27). The levels of knowledge of the students are overall decent with $65.3 \%$ respondents having good knowledge and $34.7 \%$ respondents having moderate knowledge. Based on Table 2, no students with poor knowledge on mental health recorded.

Table 2: Level of knowledge of students on mental health problems

\begin{tabular}{lll}
\hline Level of knowledge & Score & Frequency (\%) \\
\hline Poor & $1-20$ & $0(0.0)$ \\
Moderate & $21-40$ & $172(34.7)$ \\
Good & $41-60$ & $324(65.3)$ \\
\hline
\end{tabular}

Slightly above half of the respondents agreed that "Most people with mental health problems want to have paid employment" (51\%) and that "If a friend had a mental health problem, they would know what advice to give the friend to get professional help" $(50.8 \%)$. A majority of the respondents believed that medication $(65.5 \%)$ and psychotherapy $(88.5 \%)$ can be effective treatments for people with mental health problems. Besides that, the majority of the respondents neither agreed nor disagreed (53.8\%) that "People with severe mental health problems can fully recover". More than one-third of the respondents $(42.2 \%)$ agreed that "Most people with mental health problems go to a healthcare professional to get help".

Most respondents agreed that bipolar disorder (91.3\%), depression (86.1\%) and schizophrenia (85.5\%) are types of mental illness while more than half agreed that stress is also another type of mental illness $(56.4 \%)$. Likewise, almost half respondents (45.6\%) believed that "Grief" is a type of mental illness while $40.1 \%$ neither agreed nor disagreed that "Drug addiction" is a type of mental illness. Table 3 illustrates the respondents' pattern of response to each item in the knowledge section of the questionnaire. 
Attitude

Overall, the students had good attitude towards mental health disorders with majority $(99.2 \%)$ having good attitude towards mental health disorders with a mean score of 24.75 (SD 2.48). Table 4 shows the pattern of responses to each item in the attitude section.

Influence of students' characteristics on knowledge and attitude scores

There was a significant association between knowledge score $(p=0.002)$ and attitude score $(p<$ 0.001 ) with the different age groups. There was a statistically significant associations of knowledge score with ethnics $(p=0.003)$ but no significant differences were found in their attitude $(p=0.313)$. Besides, the differences between the faculties were found to be significant for both knowledge and attitude scores with a p-value of 0.001 and less than $0.001(p<0.001)$ respectively. Further significant association were also found between the different educational level of the respondents with their knowledge and attitude score $(p<0.001)$. There was no significant association found on the knowledge score with gender and previous experience of mental health disorders in self or others.

Correlation between level of knowledge and attitudes of students towards mental health disorders

A positive correlation is seen between the respondent's level of knowledge about mental health and the respondent's attitude towards mental health disorders, which was statistically significant $\left(r_{s}=0.248, \mathrm{p}<0.001\right)$ as illustrated in Table 5.

Table 3: Responses to the items in the knowledge section

\begin{tabular}{|c|c|c|c|c|c|}
\hline \multirow{2}{*}{ Item } & \multicolumn{5}{|l|}{ N (\%) } \\
\hline & SA & A & $\mathbf{N}$ & D & SD \\
\hline \multicolumn{6}{|l|}{ Part A } \\
\hline $\begin{array}{l}\text { 1. Most people with mental health problems want } \\
\text { to have paid employment. }\end{array}$ & $48(9.7)$ & $\begin{array}{l}205 \\
(41.3)\end{array}$ & $\begin{array}{l}208 \\
(41.9)\end{array}$ & $31(6.3)$ & $4(0.8)$ \\
\hline $\begin{array}{l}\text { 2. If a friend had a mental health problem, I know } \\
\text { what advice to give them to get professional } \\
\text { help. }\end{array}$ & $29(5.8)$ & $\begin{array}{l}223 \\
(45.0)\end{array}$ & $\begin{array}{l}167 \\
(33.7)\end{array}$ & $71(14.3)$ & $6(1.2)$ \\
\hline $\begin{array}{l}\text { 3. Medication can be an effective treatment for } \\
\text { people with mental health problems. }\end{array}$ & $47(9.5)$ & $\begin{array}{l}278 \\
(56.0)\end{array}$ & $\begin{array}{l}134 \\
(27.0)\end{array}$ & $32(6.5)$ & $5(1.0)$ \\
\hline $\begin{array}{l}\text { 4. Psychotherapy (e.g. talking therapy or } \\
\text { counselling) can be an effective treatment for } \\
\text { people with mental health problems. }\end{array}$ & $\begin{array}{l}131 \\
(26.4)\end{array}$ & $\begin{array}{l}308 \\
(62.1)\end{array}$ & $46(9.3)$ & $11(2.2)$ & $\begin{array}{l}0 \\
(0.0)\end{array}$ \\
\hline $\begin{array}{l}\text { 5. People with severe mental health problems } \\
\text { can fully recover. }\end{array}$ & $34(6.9)$ & $\begin{array}{l}143 \\
(28.8)\end{array}$ & $\begin{array}{l}267 \\
(53.8)\end{array}$ & $45(9.1)$ & $7(1.4)$ \\
\hline $\begin{array}{l}\text { 6. Most people with mental health problems go to } \\
\text { a healthcare professional to get help. }\end{array}$ & $31(6.3)$ & $\begin{array}{l}178 \\
(35.9)\end{array}$ & $\begin{array}{l}139 \\
(28.0)\end{array}$ & $\begin{array}{l}123 \\
(24.8)\end{array}$ & $25(5.0)$ \\
\hline \multicolumn{6}{|l|}{$\begin{array}{l}\text { Part } B \\
\text { The following items report agreement as to } \\
\text { whether each condition is a type of mental illness }\end{array}$} \\
\hline 7. Depression & $\begin{array}{l}163 \\
(32.9)\end{array}$ & $\begin{array}{l}264 \\
(53.2)\end{array}$ & $55(11.1)$ & $11(2.2)$ & $3(0.6)$ \\
\hline 8. Stress & $77(15.5)$ & $\begin{array}{l}203 \\
(40.9)\end{array}$ & $\begin{array}{l}150 \\
(30.2)\end{array}$ & $56(11.3)$ & $10(2.0)$ \\
\hline 9. Schizophrenia & $\begin{array}{l}193 \\
(38.9)\end{array}$ & $\begin{array}{l}231 \\
(46.6)\end{array}$ & $64(12.9)$ & $8(1.6)$ & $0(0.0)$ \\
\hline 10. Bipolar disorder (manic depression) & $\begin{array}{l}197 \\
(39.7)\end{array}$ & $\begin{array}{l}256 \\
(51.6)\end{array}$ & $35(7.1)$ & $8(1.6)$ & $0(0.0)$ \\
\hline 11. Drug addiction & $61(12.3)$ & $\begin{array}{l}121 \\
(26.4)\end{array}$ & $\begin{array}{l}199 \\
(40.1)\end{array}$ & 79 (15.9) & $26(5.2)$ \\
\hline 12. Grief & $48(9.7)$ & $\begin{array}{l}178 \\
(35.9)\end{array}$ & $\begin{array}{l}205 \\
(41.3)\end{array}$ & $54(10.9)$ & $11(2.2)$ \\
\hline
\end{tabular}

SA - strongly agree, $A$ - agree, $N$ - neutral, $D$ - disagree, $S D$ - strongly disagree 


\section{DISCUSSION}

The current study aimed at investigating the level of stigma towards mental health disorders among students. The few studies that have been conducted in university students in Malaysia, mainly focused on a specific part of mental health issues and not on the general mental health issue ${ }^{7}$. However, there was one study conducted in Malaysia that focused on both the knowledge and attitude of the general mental health issue ${ }^{5}$.

Overall, the respondents had good stigma related knowledge (mean score $41.85 \pm 3.27$ ) regarding the issues of mental health. The current findings display that most students have good and moderate levels of knowledge with no students having poor knowledge about mental health which is inconsistent with previous studies. A study done in Malaysia has indicated that there is poor knowledge among the respondents ${ }^{5}$ and another study conducted in Britain, Hong Kong and Malaysia showed that Malaysians had the poorest knowledge among the three countries ${ }^{6}$. This may be due to the fact that university students may have better knowledge compared to the general public. Regarding employment in people with mental health problems many of the respondents were in agreement that individuals with a mental health problem want to have paid employment which was consistent with the previous study ${ }^{19}$.

Table 4: Responses to the items in the attitude section

\begin{tabular}{|c|c|c|c|c|}
\hline \multirow[b]{2}{*}{ Item } & \multicolumn{4}{|l|}{$\mathbf{N}(\%)$} \\
\hline & SA & A & D & SD \\
\hline $\begin{array}{l}\text { 1. If I suffer from mental health problems, I would not want } \\
\text { people to know. }\end{array}$ & $80(16.1)$ & $\begin{array}{l}261 \\
(52.6)\end{array}$ & $\begin{array}{l}141 \\
(28.4)\end{array}$ & $14(2.8)$ \\
\hline $\begin{array}{l}\text { 2. A person who has visited a psychologist's office is a person } \\
\text { with mental disorder. }\end{array}$ & $0(0.0)$ & $\begin{array}{l}103 \\
(20.8)\end{array}$ & $\begin{array}{l}299 \\
(60.3)\end{array}$ & $94(19.0)$ \\
\hline 3. Anyone can suffer from mental health problems. & $\begin{array}{l}155 \\
(31.3)\end{array}$ & $\begin{array}{l}306 \\
(61.7)\end{array}$ & $34(6.9)$ & $\begin{array}{l}1 \\
(0.2)\end{array}$ \\
\hline $\begin{array}{l}\text { 4. I would find it hard to talk to someone with mental health } \\
\text { problems. }\end{array}$ & $34(6.9)$ & $\begin{array}{l}225 \\
(45.4)\end{array}$ & $\begin{array}{l}215 \\
(43.3)\end{array}$ & $22(4.4)$ \\
\hline $\begin{array}{l}\text { 5. People are generally caring and sympathetic to people } \\
\text { with mental health problems. }\end{array}$ & $23(4.6)$ & $\begin{array}{l}275 \\
(55.4)\end{array}$ & $\begin{array}{l}176 \\
(35.5)\end{array}$ & $22(4.4)$ \\
\hline $\begin{array}{l}\text { 6. People with mental health problems are often } \\
\text { dangerous/violent. }\end{array}$ & $29(5.8)$ & $\begin{array}{l}162 \\
(32.7)\end{array}$ & $\begin{array}{l}248 \\
(50.0)\end{array}$ & $57(11.5)$ \\
\hline $\begin{array}{l}\text { 7. The majority of people with mental health problems } \\
\text { recover. }\end{array}$ & $29(5.8)$ & $\begin{array}{l}262 \\
(52.8)\end{array}$ & $\begin{array}{l}197 \\
(39.7)\end{array}$ & $\begin{array}{l}8 \\
(1.6)\end{array}$ \\
\hline $\begin{array}{l}\text { 8. People with mental health problems should have the same } \\
\text { rights as anyone else. }\end{array}$ & $\begin{array}{l}121 \\
(24.4)\end{array}$ & $\begin{array}{l}312 \\
(62.9)\end{array}$ & $61(12.3)$ & $\begin{array}{l}2 \\
(0.4)\end{array}$ \\
\hline $\begin{array}{l}\text { 9. People with mental health problems are largely to blame } \\
\text { for their own condition. }\end{array}$ & $12(2.4)$ & $\begin{array}{l}111 \\
(22.4)\end{array}$ & $\begin{array}{l}296 \\
(59.7)\end{array}$ & $77(15.5)$ \\
\hline
\end{tabular}

SA - strongly agree, $A$ - agree, $N$ - neutral, $D$ - disagree, $S D$ - strongly disagree

Table 5: Correlation between knowledge and attitude of respondents

\begin{tabular}{|c|c|c|c|}
\hline & & Mental health knowledge & $\begin{array}{l}\text { Attitude towards mental } \\
\text { health disorders }\end{array}$ \\
\hline \multirow[t]{2}{*}{ Mental health knowledge } & $\begin{array}{l}r_{s} \text {-value } \\
\text { p-value }\end{array}$ & 1.000 & $\begin{array}{l}0.248 \\
<0.001\end{array}$ \\
\hline & $\mathbf{N}$ & 496 & 496 \\
\hline \multirow[t]{2}{*}{$\begin{array}{l}\text { Attitude towards } \\
\text { health disorders }\end{array}$} & $\begin{array}{l}r_{s} \text {-value } \\
\text { p-value }\end{array}$ & $\begin{array}{l}0.248 \\
<0.001\end{array}$ & 1.000 \\
\hline & $\mathbf{N}$ & 496 & 496 \\
\hline
\end{tabular}

${ }^{*} p<0.05$

Concerning recognition and support many of the respondents agreed that they would know what advice to give a friend with a mental illness to get professional help which was also found to be consistent with the previous study ${ }^{19}$. Besides that, majority of the respondents agreed that medication and psychotherapy are effective treatments of mental health disorders which was also consistent with previous studies ${ }^{17,19}$. Furthermore, under half the respondents, which still make up the majority, agree that in the matter of help-seeking, most individuals with mental illness go to healthcare professionals to get help which show that these current findings are consistent with those of previous findings $\mathrm{s}^{17,19}$. However, regarding matters of recovery the majority of the respondents were neutral to the 
notion that people with severe mental health problems fully recover from their ordeal which is inconsistent with previous findings ${ }^{17,19}$.

Pertaining to identification of types of mental illness, a majority of the respondents agreed that depression, schizophrenia and bipolar disorder (manic depression) are types of mental illness. The misconception held was that the majority of respondents believed that stress and grief are types of mental illness. Besides that, respondents were least likely to agree with drug addiction as a type of mental illness with only about slightly more than a third agreeing that drug addiction is a type of mental illness. All these findings gathered are consistent with the previous findings ${ }^{19}$.

Of all the grouped ages, respondents from the age group of 26 and above had the best knowledge as compared to the other age groups. Furthermore, Malay displayed the highest level of knowledge compared to Chinese, Indian and Others which was inconsistent from the previous study. A study conducted in Malaysia on the students of Universiti Sains Malaysia, revealed an overall moderate level of knowledge among the students regarding mental health ${ }^{7}$. In the study, it was displayed that out of the three major ethnic groups in Malaysia, the Chinese, particularly the females, have a higher knowledge on mental health compared to the Malays and Indians ${ }^{7}$.

Besides that, students from the Dentistry programme had the highest knowledge compared to students from the Medicine, Pharmacy and Nursing programme as well as the other programmes. Respondents from the degree programmes displayed better knowledge compared to those from the Foundation/Diploma programmes. This may be due to the fact that students from the degree programmes particularly healthcare students have already been exposed to the issue of mental health in their syllabus ${ }^{20}$.

With regards to attitude over half the respondents agreed that if they suffered from a mental health problem they would not want people to know. These findings are similar to findings in a study done on students of a university in Saudi Arabia ${ }^{21}$. Besides that, majority of the respondents agreed that they would find it hard to talk to someone with mental health problems which have been found to be consistent with previous literature ${ }^{5}$. Based on the findings, it was shown that the majority of the respondents agreed that anyone can suffer from mental health problems, people are generally caring and sympathetic to people with mental health problems, the majority of people with mental health problems recover and people with mental health problems should have the same right as anyone else. These findings are inconsistent with a Malaysian study ${ }^{5}$ but consistent with a study conducted in Saudi Arabia ${ }^{21}$. This could be because university students may have a better attitude towards mental health disorders as compared to the general public who have also displayed poor knowledge. Furthermore, respondents also had better attitudes as they disagreed with negative items in the questionnaire whereby they did not believe that a person who has visited a psychologist's office is a person with mental disorder, people with mental health problems are often dangerous or violent and people with mental health problems are largely to blame for their own condition which again was inconsistent with previous findings ${ }^{5}$, thus displaying that the respondents in this study have better attitudes.

Of all the age groups, the age group of 22 years old and above had the best attitude towards mental health disorders, mainly because majority of the respondents from this group were from the degree and postgraduate students, while the other age group of students were mainly diploma students. The degree and postgraduate students displayed better attitudes compared to those from the Foundation/Diploma programmes as it may be due to their better knowledge level. Besides that, Medicine students had the best attitudes followed by Dentistry students as compared to other faculties.

It was found that mental health knowledge was only influenced by ethnicity of the respondents, which is consistent with a previous study done by Nordin NM et al. ${ }^{22}$. Based on cross tabulation results, Chinese had good level of knowledge followed by Malays, Indians and other ethnicities. On the other hand, other factors like age, gender, faculty, current education level and experiences of mental health disorders in self or others played no part. No significant influence found between sociodemographic data and the level of attitudes.

There was a positive correlation between respondent's mental health knowledge and attitude towards mental health disorders which was statistically significant. These findings show some inconsistency with previous study done by Yeap and Low in $2009^{5}$.

This study can become a reference to the university and colleges administrators and authorities, as well as governmental and private agencies to enable them to understand the state of mental health literacy among Malaysian university students. Though the level of stigma among the students was generally low, there is room for improvement, particularly in the area of disclosure. A structured developmental and preventive program can be organized by university such as stress management and time management workshop. The administrator should also think of ways on improving engagement with 
students especially by mentor or counsellor and even the faculty members to address the issue of poor mental health among university students.

\section{CONCLUSIONS}

In conclusion, the knowledge and attitude of university students in this study are relatively good with the majority of the students having good knowledge and a larger majority having good attitude which shows an improvement from previous studies. The adequate level of knowledge among these students is seen to has led to good behaviour towards mental health problem. This study has the potential to increase awareness about mental health among the students as this problem is a cause for growing concern among youth. The thing about mental illness is, it is not an obvious disease or condition and it can easily be hidden behind a well-meaning smile. The increase in its prevalence over the years indicates a need for better understanding by the general public. Hence, this study can provide data on the necessity of setting up programs to improve knowledge on mental health of the people.

\section{REFERENCES}

1. World Health Organization. Mental disorders affect one in four people, WHO 2001. [cited 9 November 2017]. Available from: http: / / www.who.int/whr/2001/media_cent re/press_release/en/

2. World Health Organization. Social determinants of mental health, WHO 2014. [cited 15 November 2017]. Available from: http://www.who.int/mental_health/public ations/gulbenkian_paper_social_determinan ts_of_mental_health/en/

3. Thye LL. Mental health in the workplace. National Institute of Occupational Safety and Health (NIOSH) [cited 18 August 2019]. Available from: https: //www.thestar.com.my/opinion/lette rs/2019/07/15/mental-health-in-theworkplace\#WV2rjJRWyUhvYcrS.99

4. Thornicroft G, Rose D, Kassam A and Sartorius N. Stigma: Ignorance, prejudice or discrimination? British Journal of Psychiatry 2007; 190(3), 192-193.

5. Yeap R and Low WY. Mental health knowledge, attitude and help-seeking tendency: A Malaysian context. Singapore Medical Journal 2009; 50: 1169-1176.

6. Loo PW, Wong S, Furnham A. Mental health literacy: A cross-cultural study from Britain,
Hong Kong and Malaysia. Asia Pac Psychiatry 2012 Jun;4(2):113-25.

7. Khan TM, Sulaiman SA, Hassali MA. Mental health literacy towards depression among non-medical students at a Malaysian university. Mental Health in Family Medicine 2010;7(1):27-35.

8. Hanafiah AN, Van Bortel T. A qualitative exploration of the perspectives of mental health professionals on stigma and discrimination of mental illness in Malaysia. International Journal of Mental Health Systems 2015;9:10.

9. Phelan JC, Link BG, Stueve A and Pescosolido BA. Public conceptions of mental illness in 1950 and 1996: What is mental illness and is it to be feared?, Journal of Health and Social Behavior 2000; 41: 188-2017.

10. Kader Maideen SF, Mohd. Sidik S, Rampal L, Mukhtar F. Prevalence, Associated Factors and Predictors of Depression among Adults in the Community of Selangor, Malaysia. Stewart R, ed. PLoS ONE. 2014;9(4):e95395. doi:10.1371/journal.pone.0095395.

11. Zivin K, Eisenberg D, Gollust SE, Golberstein E. Persistence of mental health problems and needs in a college student population. $J$ Affect Disord. 2009 Oct;117(3):180-5.

12. Hamdan-Mansour AM, Halabi JO, Dawani HA. Depression, hostility, and substance use among university students in Jordan. Mental Health and Substance Use: Dual diagnosis. 2009; 2(1), 52-63.

13. Zaid ZA, Chan SC, Ho JJ. Emotional disorders among medical students in a Malaysian private medical school. Sing Med J 2007; 48(10), 895-99.

14. Sherina MS, Lekhraj R, Nadarajan K. Prevalence of emotional disorders among medical students in a Malaysian university. Asia Pac Fam Med. 2003; 2: 213-17.

15. The American College Health Association. American College Health AssociationNational college health assessment spring 2008 reference group data report (abridged), Journal of American College Health 2009; 57: 477-488.

16. Evans-Lacko S, Little $\mathrm{K}$, Meltzer $\mathrm{H}$, et al. Development and psychometric properties of 
the Mental Health Knowledge Schedule. Can J Psychiatry 2010 Jul;55(7):440-8.

17. Evans-Lacko S, Henderson C, Thornicroft G. Public knowledge, attitudes and behaviour regarding people with mental illness in England 2009-2012. Br J Psychiatry Suppl. $2013 \mathrm{Apr} ; 55: \mathrm{s} 51-7$.

18. Li J, Li J, Thornicroft G, Huang Y. Levels of stigma among community mental health staff in Guangzhou, China. BMC Psychiatry 2014; 14:231.

19. TNS BMRB. Attitudes to mental illness: 2014 research report, UK. 2015.

20. Chang S, Ong HL, Seow E, Chua BY, Abdin E, Samari E, Subramaniam M. Stigma towards mental illness among medical and nursing students in Singapore: a cross-sectional study. BMJ 2017; 7(12).
21. Mahfouz MS, Aqeeli A, Makeen AM, et al. Mental Health Literacy Among Undergraduate Students of a Saudi Tertiary Institution: A Cross-sectional Study. Ment Illn 2016 Dec 21;8(2):6806.

22. Nordin NM, Abu Talib M, Yaacob SM, Sabran MS. A Study on Selected Demographic Characteristics and Mental Health of Young Adults in Public Higher Learning Institutions in Malaysia. Glob J Heath Sci 2010 Oct;2(2). 